Supplement of Atmos. Chem. Phys., 21, 5953-5964, 2021

https://doi.org/10.5194/acp-21-5953-2021-supplement

(C) Author(s) 2021. CC BY 4.0 License.

(c) (1)
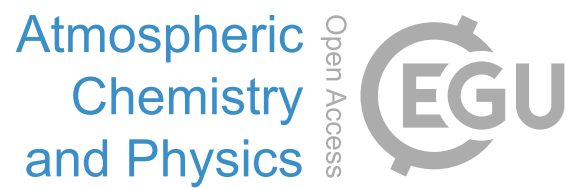

Supplement of

\title{
Firewood residential heating - local versus remote influence on the aerosol burden
}

\section{Clara Betancourt et al.}

Correspondence to: Iulia Gensch (i.gensch@fz-juelich.de)

The copyright of individual parts of the supplement might differ from the article licence. 
Table S1.1: Overview on selected LANUV filter samples from the STYR and EIFE sites. Sampling dates, filter levoglucsan loadings and main origin geographical regions for the investigated air parcels (determined by Hybrid Single-Particle Lagrangian Integrated Trajectory (HYSPLIT, http://ready.arl.noaa.gov/ HYSPLIT.php back trajectory analyses) are given. The sampling time is $24 \mathrm{~h}$ and filters are daily changed at 00:00 UTC +1 .

\begin{tabular}{|c|c|}
\hline$\cdot$ & $\begin{array}{c}\text { Sampling } \\
\text { date } \\
\text { (dd-mm-yy) }\end{array}$ \\
\hline 1 & $02-11-15$ \\
\hline 2 & $06-11-15$ \\
\hline 3 & $10-11-15$ \\
\hline 4 & $14-11-15$ \\
\hline 5 & $22-11-15$ \\
\hline 6 & $26-11-15$ \\
\hline 7 & $08-12-15$ \\
\hline 8 & $10-02-16$ \\
\hline 9 & $14-02-16$ \\
\hline 10 & $18-02-16$ \\
\hline 11 & $26-02-16$ \\
\hline 12 & $05-03-16$ \\
\hline 13 & $09-03-16$ \\
\hline 14 & $13-03-16$ \\
\hline 15 & $17-03-16$ \\
\hline 16 & $19-01-17$ \\
\hline 17 & $27-01-17$ \\
\hline 18 & $12-02-17$ \\
\hline 19 & $20-03-17$ \\
\hline 20 & $24-03-17$ \\
\hline 21 & $28-03-17$ \\
\hline 22 & $01-04-17$ \\
\hline 23 & $13-04-17$ \\
\hline 24 & $17-04-17$ \\
\hline 25 & $21-04-17$ \\
\hline
\end{tabular}

STYR \begin{tabular}{|r|l|}
\hline \multicolumn{1}{|c|}{$\begin{array}{l}\text { LG } \\
\text { ng }\end{array}$} & \multicolumn{1}{|c|}{ Main origin regions } \\
\hline 18910 & Southeast Europe \\
\hline 10667 & France / Atlantic Ocean \\
\hline 15128 & Atlantic Ocean \\
\hline 3297 & Atlantic Ocean (France, UK) \\
\hline 65942 & Arctic Ocean, Scandinavia \\
\hline 12801 & Arctic Ocean \\
\hline 20752 & France, Mediterranean Sea \\
\hline 65942 & Southern / Eastern Europe \\
\hline 62936 & Southern Germany, France \\
\hline 8825 & France, Atlantic Ocean, UK \\
\hline 89798 & France \\
\hline 30159 & France, Benelux, UK \\
\hline 26765 & Southern Germany, France \\
\hline 68852 & Eastern Europe \\
\hline 13867 & Eastern Europe \\
\hline 235065 & Eastern Europe \\
\hline 37238 & Southern Europe \\
\hline 60589 & Southern Europe \\
\hline 25601 & Atlantic Ocean \\
\hline 16136 & Europe \\
\hline 23041 & France, Southern Germany \\
\hline 14662 & Benelux \\
\hline 12413 & UK \\
\hline 26299 & Northern Atlantic, UK \\
\hline 4655 & Northern Atlantic, UK \\
\hline & \\
\hline 120
\end{tabular}

\begin{tabular}{|c|c|c|}
\hline EIFE & $\begin{array}{c}\mathrm{LG} \\
/ \mathrm{ng}\end{array}$ & Main origin regions \\
\hline & 9503 & Southern Germany \\
\hline & 3976 & France / Atlantic Ocean \\
\hline & 8437 & Atlantic Ocean \\
\hline & 5140 & Atlantic Ocean (France, UK) \\
\hline & 12219 & Arctic Ocean, Scandinavia \\
\hline & 3976 & Arctic Ocean \\
\hline & 5915 & France, Mediterranean Sea \\
\hline & 25019 & Southern Europe \\
\hline & 33262 & Southern / Eastern Europe \\
\hline & 3103 & Southern Germany, France \\
\hline & 18619 & Benelux, UK \\
\hline & 18716 & France, Benelux, UK \\
\hline & 15419 & Southern Germany, France \\
\hline & 28026 & Eastern Europe \\
\hline & 9213 & Eastern Europe \\
\hline & 73778 & Eastern Europe \\
\hline & 10939 & Southern Europe \\
\hline & 28472 & Southern Europe \\
\hline & 22886 & Atlantic Ocean \\
\hline & 8922 & Europe \\
\hline & 10318 & France, Southern Germany \\
\hline & 6672 & Benelux \\
\hline & 5974 & UK \\
\hline & 9542 & Northern Atlantic, UK \\
\hline & 5818 & Northern Atlantic, UK \\
\hline
\end{tabular}


30 Table S1.2: Average temperature during the sampling periods (from ECMWF meteorology)

\begin{tabular}{|r|c|c|c|}
\cline { 2 - 4 } \multicolumn{1}{c|}{} & $\begin{array}{c}\text { Sampling date } \\
\text { [dd-mm-yy] }\end{array}$ & $\begin{array}{c}\text { average } \\
\text { temperature } \\
\text { EIFE }\left[{ }^{\circ} \mathrm{C}\right]\end{array}$ & $\begin{array}{c}\text { average } \\
\text { temperature } \\
\text { STYR }\left[{ }^{\circ} \mathrm{C}\right]\end{array}$ \\
\hline 1 & $02-11-15$ & 8.81 & 7.77 \\
\hline 2 & $06-11-15$ & 14.14 & 14.98 \\
\hline 3 & $10-11-15$ & 11.88 & 13.70 \\
\hline 4 & $14-11-15$ & 7.04 & 8.13 \\
\hline 5 & $22-11-15$ & 0.89 & 2.07 \\
\hline 6 & $26-11-15$ & 2.42 & 3.71 \\
\hline 7 & $08-12-15$ & 9.63 & 10.31 \\
\hline 8 & $10-02-16$ & 2.47 & 4.02 \\
\hline 9 & $14-02-16$ & 1.64 & 2.14 \\
\hline 10 & $18-02-16$ & 0.66 & 1.74 \\
\hline 11 & $26-02-16$ & 0.91 & 1.65 \\
\hline 12 & $05-03-16$ & 0.88 & 2.66 \\
\hline 13 & $09-03-16$ & 2.18 & 3.82 \\
\hline 14 & $13-03-16$ & 2.49 & 3.45 \\
\hline 15 & $17-03-16$ & 3.29 & 5.31 \\
\hline 16 & $19-01-17$ & -6.66 & -1.84 \\
\hline 17 & $27-01-17$ & 0.44 & 1.50 \\
\hline 18 & $12-02-17$ & 2.28 & 2.62 \\
\hline 19 & $20-03-17$ & 9.25 & 10.80 \\
\hline 20 & $24-03-17$ & 7.81 & 8.77 \\
\hline 21 & $28-03-17$ & 13.23 & 12.82 \\
\hline 22 & $01-04-17$ & 11.19 & 12.72 \\
\hline 23 & $13-04-17$ & 8.53 & 9.49 \\
\hline 24 & $17-04-17$ & 4.94 & 6.54 \\
\hline 25 & $21-04-17$ & 7.46 & 9.15 \\
\hline & & & \\
\hline
\end{tabular}




\section{S2 Experimental methods for measurement of levoglucosan concentration and isotopic composition}

\section{Concentration}

40 Ambient levoglucosan concentrations were determined at LANUV by ion chromatography (871 Advanced Bioscan equipped with 818 IC Pump, Metrohm Deutschland GmbH, Filderstadt, Germany). The suspension was produced with $40 \mathrm{ml}$ of ultrapure water in which up to six filter sections of $23 \mathrm{~mm}$ diameter are shaken for $60 \mathrm{~min}$ in a $50 \mathrm{ml}$ PE centrifuge tube. Samples were injected intro chromatograph using a sample processor (Metrohm 853, Metrohm Deutschland $\mathrm{GmbH}$, Filderstadt, Germany). Chromatography was conducted at $297 \mathrm{~K}$ with a flow of $0.7 \mathrm{ml} \mathrm{min}^{-1}$

45 at approx. 5.5 MPa using $1.5 \mathrm{~g} \mathrm{NaOH}$ and $0.4 \mathrm{~g}$ sodium acetate in $1 \mathrm{~kg}$ of water as an eluent. More details concerning the method applied for determination of levoglucosan concentrations can be found in (Pfeffer et al., 2013). The detection limit of this method was determined to be at $10 \mathrm{ng} \mathrm{m}-3$.

\section{Isotopic composition}

LiquidExtraction ThermoDesorption TwoDimensionalGasChromatography IsotopeRatioMassSpectrometry (LETD-2DGC-IRMS) is employed off-line to determine levoglucosan isotope ratios in the sampled aerosol particles. The method developed by (Gensch et al., 2018) was further optimized, to improve the precision and accuracy of the heart-cut TD-2DGC-IRMS measurements. To avoid matrix effects, which lead to a lack of the GC separation 55 efficiency, a HPLC-purification of the samples was integrated in the methodology. Small filter cuts are extracted twice by $10 \mathrm{ml}$ Milli-Q water each in an ultrasonic bath (BANDELIN electronic GmbH, Berlin, Germany) for 15 min. The extracts are filtered using membrane filter Millex GP $13 \mathrm{~mm}$ PES $0.22 \mu \mathrm{m}$ (Merk KGaA, Darmstadt, Germany). The two fractions of extracts and the portion used to rinse the vial walls were mixed together and directly transferred into a TurboVap 500 Evaporator Workstation (John Morris Scientific, Sydney, Australia). This was

60 beforehand cleaned with Millipore water and ethanol (99.99 \%, Merk KGaA, Darmstadt, Germany). The collected solution was concentrated at $333 \mathrm{~K}$ to a volume of ca. $0.5 \mathrm{ml}$. This batch is transferred to a $1.5 \mathrm{ml}$ vial. The walls of the TurboVap vessels were rinsed three times with a total of $0.4 \mathrm{ml}$ Milli-Q water, which are added to the concentrate, which is then placed in a freezer kept at $257 \mathrm{~K}$. The frozen samples are freeze-dried using a freezedryer Christ Alpha 1-2 LD plus (Martin Christ Gefriertrocknungsanlagen GmbH, Germany). The pressure is 65 immediately reduced to $2-3 \mathrm{~Pa}$. In that way the samples stay solid. Under $611 \mathrm{~Pa}$, the sublimation starts. Since the instrument is not thermo-isolated, the samples slowly took the temperature of the surroundings, intensifying the ongoing sublimation process. $100 \mu \mathrm{l}$ Milli-Q water are added to the dried samples. To reduce matrix effects, the 
aqueous sample extracts are 'purified' by high performance liquid chromatography (HPLC) using a polar Carbohydrate $\mathrm{Ca} 2+$ column (10x4 mm CS-Chromatographie, Langerwehe) and water as eluent. At the front of the 70 separating column, a pre-column (MultoHigh 100RP 18-3 $\mu \mathrm{m}, 10 \mathrm{x} 4 \mathrm{~mm}$ length) (Carbohydrate $\mathrm{Ca}^{\wedge}(2+) 10 * 4 \mathrm{~mm}$ Chromatographie Service GmbH, Langerwehe, Germany) is attached, to avoid contaminations of the main column. For the levoglucosan detection, a differential refractometer (KNAUER GmbH, Berlin, Germany), is used. The solvent reservoir is filled with Millipore water. The column was flushed with this eluent for half an hour, to clean the system and to stabilize the base line. The flow rate through the capillary tube is $0.75 \mathrm{ml} \mathrm{min}{ }^{-1}$. The pressure is 75 kept at 64 bar. The column oven temperature is set to $298 \mathrm{~K}$. The analyte extracts are injected in the HPLC and the fraction containing levoglucosan are collected into glass vials. During the HPLC sampling window, ca $1.5 \mathrm{~mL}$ levoglucosan eluent is collected. To prevent the presence of water in the CG-IRMS system, water must be removed by freeze-drying. After the freeze drying of the HPLC solutions, the vial walls are thoroughly rinsed using methanol. A rigorous wash-out, by repeated rinsing-concentrating procedures, is mandatory to prevent any wall

80 losses which can lead at this trace amount level of investigated compound even to a complete waste of levoglucosan. Eventually, the volume of dissolving methanol adjusted to reach a concentration of $\sim 200 \mathrm{ng} / \mu \mathrm{l}$. The vials are stored in a refrigerator at $277 \mathrm{~K}$ until the isotopic measurements.

The instrumental setup for isotopic measurements consists of three major sections (i) a thermal desorption/cryo focusing unit, (ii) a gas-chromatograph-separation unit and (iii) a Detection unit. The aim of the first unit is to 85 concentrate and focus the compounds prior to injection into the gas chromatograph. This section consists of two components; a Thermal Desorption Unit (TDU) (GERSTEL GmbH, Germany) mounted on the top of a Cooled Injection System (CIS) (GERSTEL GmbH, Germany). The TDU utilizes heat and flow of inert gas (He, 99.9999 $\%$ AIR LIQUID GmbH, Germany) to thermo-desorb the analyte mixture from the quartz wool placed in a TDU tube. The compounds are volatilized and then trapped in the CIS at low temperature. The CIS is subsequently

90 heated to release the organic compounds and transfer them into the GC (Agilent 6890, Agilent Technologies USA). Two dimensional GC is used to separate the component of interest from the others in the mixture. It is equipped with two columns. The first column is nonpolar (Rtx-1301, $30 \mathrm{~m}$ length, $0.32 \mathrm{~mm}$ i.d., $0.25 \mu \mathrm{m}$ film thickness), being used to separate the compounds depending on their volatility. The second column (FS-OV-225-CB -0.25, 30 $\mathrm{m}$ length, $0.25 \mathrm{~mm}$ i.d., $0.25 \mu \mathrm{m}$ film thicknesses) is polar and utilized for a better resolution and selectivity of 95 polar compounds and thus, to optimally separate the levoglucosan. Two four port valves are mounted on the GC to choose different operating configurations and thus to enable the two dimensional 'heart-cut' separation. According to that, during the heart-cut stage, the eluent is directed through the first column into the additional Cryo Trapped System (CTS), were the compounds of interest are trapped at very low temperatures. After separation by the 
second column, 25\% of the sample is sent to the Mass Spectrometer Detector (MSD) (5975C inert XL MSD,

100 Agilent technologies, USA), whereas the rest of the sample is transferred to the oxidation reactor (Thermo Scientific Bremen, Germany), where the hydrocarbons are completely oxidized to $\mathrm{CO} 2$ and water. The water is removed by using a semi permeable Nafion membrane (Thermo Scientific GmbH., Bremen, Germany). The carbon dioxide is transferred to the Isotope Ratio Mass Spectrometer (IRMS) via a continuous flow, open split device (ConFlo-IV) (Thermo Scientific GmbH., Bremen, Germany).

105 The Heart Cut TD-2DGC-IRMS Method: $1 \mu \mathrm{L}$ of the pre-cleaned mixture is injected on a small piece of quartz wool placed inside a the TDU glass tube $\left(60 \mathrm{~mm}, 4 \mathrm{~mm}\right.$ i.d., preconditioned at $623 \mathrm{~K}$ for 4 hours with $100 \mathrm{ml} \mathrm{min}^{-}$ ${ }^{1} \mathrm{He}$ flow). The tube is introduced into the TDU. The thermal desorption of the analytes spread on the wool is obtained by ramping the temperature of the TDU from 318 to $573 \mathrm{~K}$ at a rate of $500 \mathrm{~K} \mathrm{~min}-1$. The thermo-desorbed mixture is thus sent to the CIS (set at $243 \mathrm{~K}$ ) by helium at a vent flow of $150 \mathrm{ml} \mathrm{min-1.} \mathrm{After} \mathrm{complete} \mathrm{trapping,}$

110 the CIS is heated to $503 \mathrm{~K}$ at a rate of $12 \mathrm{~K} \mathrm{~s}^{-1}$. The focused compound mixture is transferred splitless at $2.5 \mathrm{ml}$ $\min ^{-1}$ to the GC. The GC oven temperature program depends of the used dimension of the GC separation. For the preliminary run to determine the levoglucosan retention time (RT), only one temperature-increasing ramp is run. The initial temperature is kept for $10 \mathrm{~min}$ at $333 \mathrm{~K}$. Subsequently, the temperature is ramped to $473 \mathrm{~K}$ at a rate of $10 \mathrm{~K} \mathrm{~min}-1$ maintaining it for $10 \mathrm{~min}$. The derived RT for levoglucosan is $14.3 \mathrm{~min}$. The two dimensional 115 separation is achieved in three stages: (i) from 0-11.5 min, the eluent from column 1 is directed to the FID; (ii) after $11.5 \mathrm{~min}$, the four-port valves are switched to trigger the transfer of the column 1 eluent to the CTS, which was previously cooled to $173 \mathrm{~K}$. (iii) At 19.5 minutes, both valves are switched to establish the configuration for separation on column 2. At $20 \mathrm{~min}$, the CTS is abruptly heated (at $20 \mathrm{~K} \mathrm{~s}^{-1}$ to $473 \mathrm{~K}$, to send the thermo-desorbed compounds into the second column. The separated compounds are sent to MSD for the peak identification and to

120 IRMS for the isotope ratios measurements. When using the heart-cut two-dimensional GC separation, two ramps in the oven temperature program are necessary. The initial temperature is $353 \mathrm{~K}$, being maintained for 1 min. During the 'transfer' and 'trapping' stages, the oven temperature was increased by $10 \mathrm{~K} \mathrm{~min}^{-1}$ to $473 \mathrm{~K}$ and was kept there for $1 \mathrm{~min}$, till the end of the heart-cut time window (from 11.5 to $19.5 \mathrm{~min}$ ). At $16 \mathrm{~min}$, the oven is cooled to 363 $\mathrm{K}$ at a rate of $50 \mathrm{~K} \mathrm{~min}^{-1}$ and kept for $1 \mathrm{~min}$. The temperature is then ramped to $513 \mathrm{~K}$ at a rate of $5 \mathrm{~K}$ min-1 and 125 maintained there for $10 \mathrm{~min}$ for the separation on the second column. The heart-cut 2DGC method delivers baseline, well separated peaks. 


\section{S3 Basic statistics of measurement results}

Table S3: Basic statistics of the experimental results. For the frequency distribution analysis, the concentration 130 and isotope ratio data were divided in $25 \mathrm{ng} \mathrm{m}-3$ and $0.5 \%$ bins, respectively. For the observed number of occurrences, Gauss functions were fitted. The amplitudes, mean values and $1 \sigma$ standard deviations are given for the derived modes.

\begin{tabular}{|l|l|l|}
\multicolumn{1}{c}{ EIFE } & \multicolumn{1}{c|}{ STYR } \\
\hline $\begin{array}{l}\text { Number of } \\
\text { samples }\end{array}$ & 25 & 25 \\
\hline
\end{tabular}

\section{Concentration / $\mathbf{n g ~ m}^{-3}$}

\begin{tabular}{|l|l|l|}
\hline mean & 54.18 & 152.13 \\
\hline std deviation & 35.80 & 124.09 \\
\hline \multicolumn{2}{|l|}{} \\
\hline min & 12.36 & 25.41 \\
\hline $10 \%$ percentile & 18.46 & 41.72 \\
\hline median & 30.19 & 85.26 \\
\hline $90 \%$ percentile & 104.21 & 282.10 \\
\hline $\max$ & 156.74 & 509.48 \\
\hline
\end{tabular}

\begin{tabular}{|l|l|l|}
\hline & & amplitude: $5.3 \pm 0.6$ \\
Frequency & amplitude: $9.9 \pm 1.0$ & mean: $62.4 \pm 3.4$ \\
distribution & mean: $34.8 \pm 2.0 \pm 3.5$ \\
& $\sigma: 19.5 \pm 2.2$ & amplitude: $2.9 \pm 0.4$ \\
& & mean: $204.5 \pm 4.3$ \\
& & $\sigma: 24.6 \pm 4.3$ \\
\hline
\end{tabular}

\begin{tabular}{|c|c|c|}
\hline mean & 2350 & 2 \\
\hline std & 0.99 & 1.03 \\
\hline
\end{tabular}

\begin{tabular}{|l|l|l|}
\hline $\min$ & -25.78 & -26.26 \\
\hline $10 \%$ percentile & -24.53 & -24.63 \\
\hline median & -23.55 & -23.30 \\
\hline $90 \%$ percentile & -22.64 & -22.21 \\
\hline $\max$ & -21.30 & -21.79 \\
\hline
\end{tabular}

\begin{tabular}{|l|l|l|}
\hline Frequency & amplitude: $6.4 \pm 1.0$ & amplitude: $5.4 \pm 0.4$ \\
distribution & mean: $-23.3 \pm 0.1$ & mean: $-23.3 \pm 0.1$ \\
& $\sigma: 0.7 \pm 0.1$ & $\sigma: 0.9 \pm 0.1$ \\
\hline
\end{tabular}




\section{S4 Modeling method}

The modeling setup (Figure S4) provides a framework for the source apportionment of biomass burning aerosol and its fate during transport. Gridded meteorological input data delivers the necessary wind fields to describe transport by advection and diffusion. FLEXPART is run backwards from the sampling points to investigate the origin of the sampled air masses. Chemical loss and deposition are included in the runs. The output of a backwards

140 run is called ,retroplume', and represents sensitivity fields of the receptor to potential upwind sources. Retroplumes can be linked with emission inventories, using the ,folded retroplume technique'. For this, a footprint layer that contains the emissions is defined. Since the case study is carried out in the cold season, levoglucosan emissions originate mainly from domestic heating with firewood. The result of the folding is a data field that describes the contribution of individual upwind domestic heating sources to the receptor. Adding up all contributions, the

145 concentration at the receptor is obtained. When releasing two isotope tracers ${ }^{12} \mathrm{LG}$ and ${ }^{13} \mathrm{LG} \delta^{13} \mathrm{C}$ can be calculated at the receptor. These modeling results can be compared with isotopic- and concentration measurements at the sampling sites. A closure study between modeling and measurements validates the modeling and leads to a better understanding of sources and processes of biomass burning aerosol.

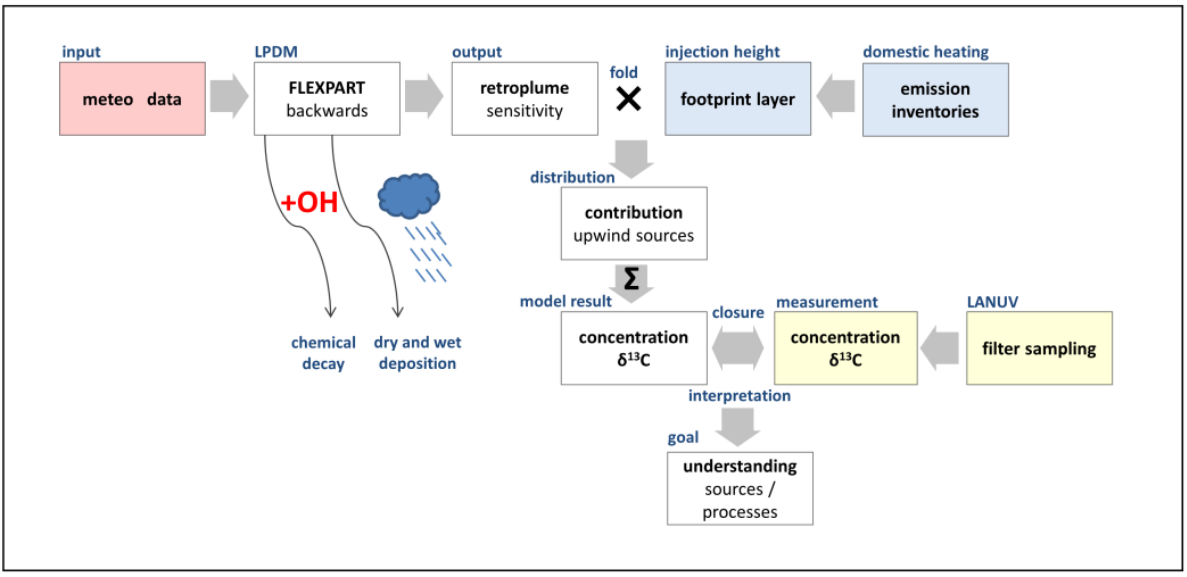

Figure S4: Modeling flow chart. Details are given in the text. 


\section{S5 Approach to determine levoglucosan emission inventories for firewood burning in the cold season, used to initialize the FLEXPART concentration and isotopic calculations}

In the following, we derive from known data levoglucosan emission fields, $S=\frac{m_{L G}}{A \cdot t}$, which are required for the folding calculations to determine levoglucosan concentration and isotopic composition at the receptor.

To this end, the annual firewood consumption of European countries, provided by the United Nations ${ }^{1}$, is divided by the total population of each country to obtain the per capita and time consumption of firewood $\left(\frac{V_{\text {firewood }}}{N_{\text {person }} \cdot t}\right)$. There

160 are several studies that divide living areas into the different categories ,city ${ }^{6}$, ,suburbs ${ }^{6}$, ,close to a city ${ }^{6}$ and ,rural ${ }^{6}$ (Döring et al., 2016), or address wood stove exhaust down to the single chimney (Baumbach et al., 2010). Such consideration is beyond the scope of this Europe-wide study. Here, the per capita consumption is weighted with the population density $\left(\frac{N_{\text {person }}}{A}\right)$ which is given with a spatial resolution of $0.25^{\circ} \times 0.25^{\circ}$, yielding a continuous area consumption of firewood with the same resolution $\left(\frac{V_{\text {firewood }}}{A \cdot t}\right)$.

165 Levoglucosan emission fields are derived as following:

$S=f_{v} \cdot f_{L G} \cdot \frac{V_{\text {firewood }}}{A \cdot t}$

where $f_{v}$ is a density conversion factor of $500 \pm 200 \mathrm{~kg} \mathrm{~m}^{-3}$ (Döring et al., 2016) and $f_{L G}$ is the average emission factor of $200 \mathrm{mg} \mathrm{LG} \mathrm{kg}^{-1}$ for firewood. Furthermore the consumption is weighted with individual factors ${ }^{2}$ for every month, to describe seasonal variability in the wood consumption. Uncertainties are related to density variability of

170 woods used in Europe for heating, different heating behaviour as well as unresolved $f_{L G}$ due to e.g. unknown type of firewood or burning conditions, (Akagi et al., 2011) and references therein.

The domestic heating emission enters the atmosphere as a hot plume of wood smoke with an injection height of 100-300 m (Hueser et al., 2017). This 'footprint layer' contains the volume emission data needed for the folding calculations: $\frac{m_{L G}}{V \cdot t}$

175 To this end, the retroplume transmission corrected residence time (Seibert and Frank, 2004) in the grid cell is multiplied with the emission being injected into that cell to determine the contribution of individual sources to the levoglucosan concentration at the receptor $\left(\frac{m_{L G}}{V}\right)$.

\footnotetext{
${ }^{1}$ Firewood combustion data is obtained from statistical databases provided by the United Nations: data.un.org/Data.aspx?d=EDATA\&f=cmID\%3aFW\%3btrID\%3a1231, access March 10th 2017.

${ }^{2}$ Monthly weighting is estimated from a personal survey.
} 
Adding up all contributions from all sources, the concentration at the receptor is determined:

$C=\sum \frac{m_{L G}}{V}$

180 Furthermore, for isotope ratio calculation it must be considered that the ${ }^{13} \mathrm{LG}$ emissions can be derived from the source isotopic ratio:

$S_{13} L G=\frac{m^{13} L G}{A \cdot t}=\frac{m^{12} L G \cdot R_{0}}{A \cdot t}=R_{0} \cdot S^{12} L G$

where $S_{12} L G$ and $S_{13} L G$ are the emissions of the two levoglucosan isotopologues and $R_{0}$ is the source specific isotope ratio. $T$ The residence times $t_{r e s,{ }^{12} L G}$ and $t_{r e s,{ }^{13} L G}$ are calculated in the retroplumes depending on the rate

185 for the photo-chemical degradation of ${ }^{12} L G$ and ${ }^{13} L G$ by $\mathrm{OH}$, respectively. Thus, the absolute isotope ratios $R_{t}$ can be obtained in each grid and thus, at the receptor.

$R_{t}=\frac{\sum \frac{m^{13} L G}{V \cdot t} \cdot t_{r e s,{ }^{13} L G}}{\sum \frac{m^{12} L G}{V \cdot t} \cdot t_{r e s,{ }^{12} L G}}$ 
S6 Model results using ECMWF vs. GFS meteorological input data

Table S6.1: Comparison of model results obtained with ECMWF/GFS meteorological input data at the EIFE station. Differences for the $\delta^{13} \mathrm{C}$ and concentration data are given in $\%$ and $\%$, respectively.

\begin{tabular}{|c|c|}
\hline Nr. & $\begin{array}{c}\text { Sampling } \\
\text { date } \\
\text { (dd-mm-yy) }\end{array}$ \\
\hline 1 & $02-11-15$ \\
\hline 2 & $06-11-15$ \\
\hline 3 & $10-11-15$ \\
\hline 4 & $14-11-15$ \\
\hline 5 & $22-11-15$ \\
\hline 6 & $26-11-15$ \\
\hline 7 & $08-12-15$ \\
\hline 8 & $10-02-16$ \\
\hline 9 & $14-02-16$ \\
\hline 10 & $18-02-16$ \\
\hline 11 & $26-02-16$ \\
\hline 12 & $05-03-16$ \\
\hline 13 & $09-03-16$ \\
\hline 14 & $13-03-16$ \\
\hline 15 & $17-03-16$ \\
\hline 16 & $19-01-17$ \\
\hline 17 & $27-01-17$ \\
\hline 18 & $12-02-17$ \\
\hline 19 & $20-03-17$ \\
\hline 20 & $24-03-17$ \\
\hline 21 & $28-03-17$ \\
\hline 22 & $01-04-17$ \\
\hline 23 & $13-04-17$ \\
\hline 24 & $17-04-17$ \\
\hline 25 & $21-04-17$ \\
\hline
\end{tabular}

\begin{tabular}{|c|c|c|c|c|c|}
\hline ECMWF & GFS & & ECMWF & GFS & \\
\hline $\begin{array}{l}\delta_{\bmod } \\
/ \% 0\end{array}$ & $\begin{array}{l}\delta_{\bmod } \\
/ \% 0\end{array}$ & $\begin{array}{l}\delta_{\text {diff }} \\
/ \% 0\end{array}$ & $\begin{array}{c}\mathrm{c}_{\bmod } \\
/ \mathrm{ng} \mathrm{m}^{-3}\end{array}$ & $\begin{array}{c}\mathrm{c}_{\text {mod }} \\
/ \mathrm{ng} \mathrm{m}^{-3}\end{array}$ & $\begin{array}{l}\mathrm{c}_{\text {diff }} \\
/ \%\end{array}$ \\
\hline-23.02 & -23.11 & -0.09 & 59.79 & 55.84 & -6.61 \\
\hline-23.48 & -23.48 & 0.00 & 23.96 & 25.38 & 5.93 \\
\hline-23.35 & -23.43 & -0.08 & 44.45 & 33.82 & -23.91 \\
\hline-23.49 & -23.47 & 0.02 & 28.93 & 31.42 & 8.59 \\
\hline-23.63 & -23.71 & -0.07 & 19.78 & 18.05 & -8.76 \\
\hline-23.68 & -23.71 & -0.03 & 19.48 & 18.50 & -5.01 \\
\hline-23.11 & -23.18 & -0.07 & 47.03 & 40.40 & -14.08 \\
\hline-23.53 & -23.53 & -0.01 & 26.37 & 25.89 & -1.84 \\
\hline-23.05 & -23.01 & 0.04 & 79.93 & 83.21 & 4.10 \\
\hline-22.88 & -22.88 & 0.00 & 50.91 & 51.66 & 1.46 \\
\hline-23.32 & -23.37 & -0.05 & 36.90 & 32.32 & -12.42 \\
\hline-23.30 & -23.17 & 0.13 & 39.11 & 72.83 & 86.22 \\
\hline-23.06 & -23.10 & -0.04 & 52.10 & 50.75 & -2.58 \\
\hline-23.22 & -23.26 & -0.03 & 36.08 & 32.21 & -10.73 \\
\hline-23.01 & -22.99 & 0.02 & 60.03 & 60.66 & 1.05 \\
\hline-23.27 & -23.42 & -0.15 & 38.93 & 26.46 & -32.04 \\
\hline-22.98 & -23.09 & -0.11 & 65.05 & 45.85 & -29.51 \\
\hline-22.87 & -22.98 & -0.11 & 98.36 & 62.45 & -36.50 \\
\hline-23.46 & -23.52 & -0.06 & 31.37 & 26.64 & -15.07 \\
\hline-22.97 & -23.13 & -0.15 & 61.40 & 42.05 & -31.52 \\
\hline-23.17 & -23.17 & 0.00 & 51.47 & 46.08 & -10.46 \\
\hline-23.53 & -23.43 & 0.10 & 20.72 & 27.06 & 30.62 \\
\hline-23.67 & -23.74 & -0.07 & 19.48 & 17.34 & -11.01 \\
\hline-23.66 & -23.69 & -0.02 & 19.68 & 19.07 & -3.12 \\
\hline-23.46 & -23.57 & -0.11 & 24.98 & 21.02 & -15.85 \\
\hline
\end{tabular}




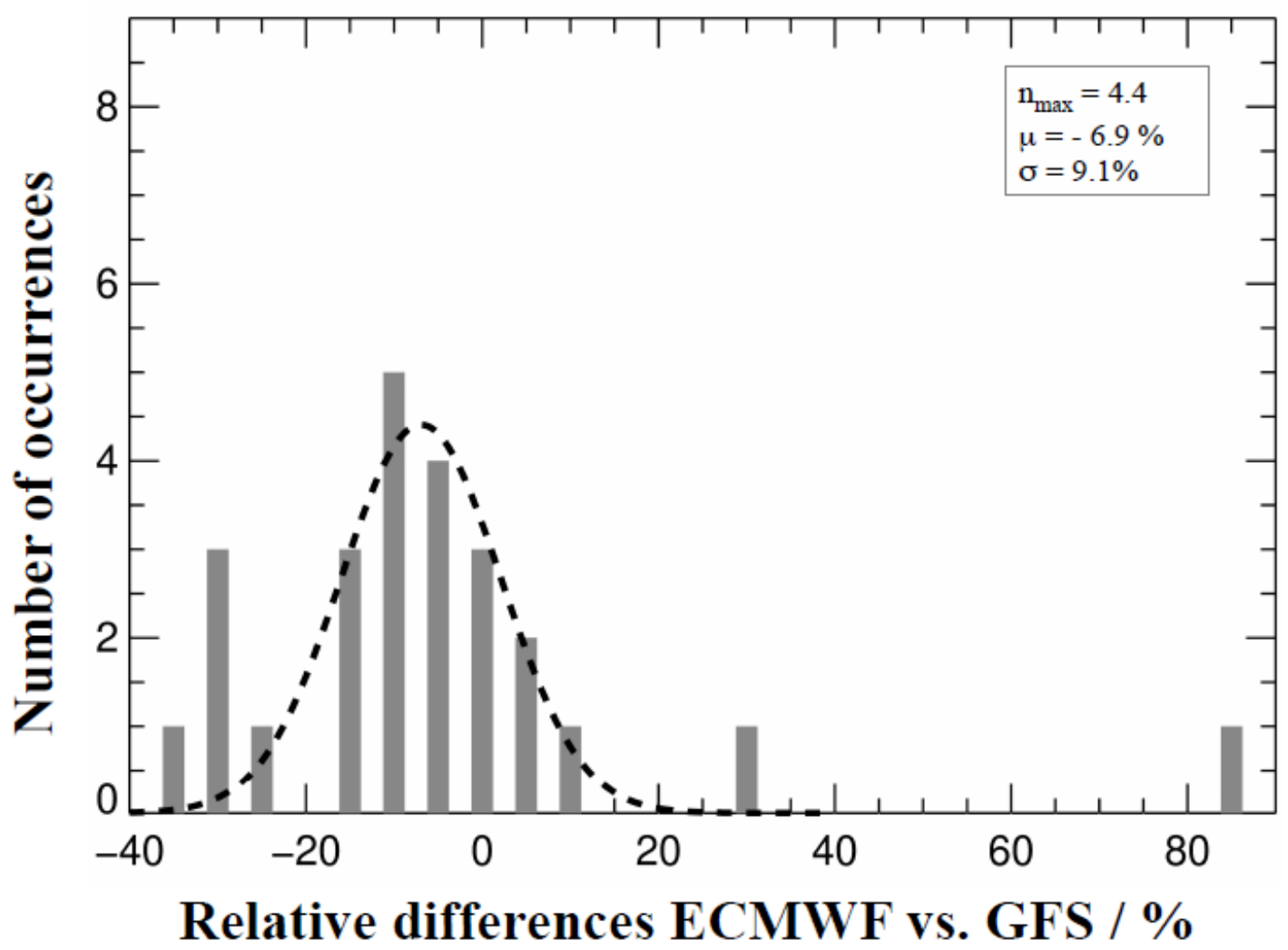

195 Figure S6.1: Distribution frequency of the relative differences in the calculated concentrations by using ECMWF vs. GFS meteorological data at the EIFE site 
Table S6.2: Comparison of model results obtained with ECMWF/GFS meteorological input data at the STYR

station. Differences for the $\delta^{13} \mathrm{C}$ and concentration data are given in \%o and \%, respectively.

\begin{tabular}{|c|c|}
\hline Nr. & $\begin{array}{c}\text { Sampling } \\
\text { date } \\
\text { (dd-mm-yy) }\end{array}$ \\
\hline 1 & $02-11-15$ \\
\hline 2 & $06-11-15$ \\
\hline 3 & $10-11-15$ \\
\hline 4 & $14-11-15$ \\
\hline 5 & $22-11-15$ \\
\hline 6 & $26-11-15$ \\
\hline 7 & $08-12-15$ \\
\hline 8 & $10-02-16$ \\
\hline 9 & $14-02-16$ \\
\hline 10 & $18-02-16$ \\
\hline 11 & $26-02-16$ \\
\hline 12 & $05-03-16$ \\
\hline 13 & $09-03-16$ \\
\hline 14 & $13-03-16$ \\
\hline 15 & $17-03-16$ \\
\hline 16 & $19-01-17$ \\
\hline 17 & $27-01-17$ \\
\hline 18 & $12-02-17$ \\
\hline 19 & $20-03-17$ \\
\hline 20 & $24-03-17$ \\
\hline 21 & $28-03-17$ \\
\hline 22 & $01-04-17$ \\
\hline 23 & $13-04-17$ \\
\hline 24 & $17-04-17$ \\
\hline 25 & $21-04-17$ \\
\hline & \\
\hline 12
\end{tabular}

STYR

\begin{tabular}{|c|c|c|c|c|c|}
\hline ECMWF & GFS & & ECMWF & GFS & \\
\hline$\delta \bmod$ & $\begin{array}{c}\delta \bmod \\
/ \% 0\end{array}$ & $\begin{array}{c}\delta \text { diff } \\
/ \% 0\end{array}$ & $\begin{array}{l}\mathrm{cmod} \\
/ \mathrm{ng} \mathrm{m}^{-3}\end{array}$ & $\begin{array}{l}\mathrm{c} \mathrm{mod} \\
/ \mathrm{ng} \mathrm{m}^{-3}\end{array}$ & $\begin{array}{c}c \operatorname{diff} \\
/ \%\end{array}$ \\
\hline-23.09 & -23.16 & -0.07 & 81.17 & 75.02 & -7.58 \\
\hline-23.32 & -23.32 & 0.00 & 42.43 & 44.14 & 4.02 \\
\hline-23.51 & -23.53 & -0.01 & 28.66 & 27.90 & -2.66 \\
\hline-23.56 & -23.57 & -0.02 & 25.89 & 24.88 & -3.89 \\
\hline-23.63 & -23.66 & -0.03 & 21.02 & 20.01 & -4.80 \\
\hline-23.60 & -23.62 & -0.02 & 24.26 & 23.19 & -4.40 \\
\hline-23.15 & -23.20 & -0.05 & 56.56 & 45.69 & -19.22 \\
\hline-23.49 & -23.51 & -0.03 & 29.84 & 28.28 & -5.25 \\
\hline-23.06 & -23.07 & -0.01 & 152.61 & 151.53 & -0.71 \\
\hline-22.91 & -22.91 & 0.00 & 75.21 & 82.50 & 9.70 \\
\hline-23.32 & -23.29 & 0.03 & 55.14 & 62.79 & 13.87 \\
\hline-23.18 & -23.30 & -0.12 & 108.46 & 70.36 & -35.13 \\
\hline-23.01 & -23.06 & -0.05 & 64.39 & 65.64 & 1.94 \\
\hline-23.26 & -23.29 & -0.03 & 44.16 & 38.95 & -11.81 \\
\hline-23.17 & -23.16 & 0.00 & 67.41 & 64.24 & -4.70 \\
\hline-23.33 & -23.39 & -0.05 & 51.36 & 46.94 & -8.60 \\
\hline-23.00 & -23.09 & -0.09 & 91.16 & 72.01 & -21.01 \\
\hline-22.88 & -22.95 & -0.08 & 112.18 & 106.81 & -4.79 \\
\hline-23.46 & -23.40 & 0.06 & 33.47 & 40.58 & 21.25 \\
\hline-23.13 & -23.25 & -0.12 & 57.77 & 47.79 & -17.28 \\
\hline-23.06 & -23.04 & 0.02 & 76.51 & 83.52 & 9.16 \\
\hline-23.35 & -23.29 & 0.06 & 36.94 & 47.42 & 28.37 \\
\hline-23.77 & -23.77 & 0.00 & 16.99 & 16.90 & -0.56 \\
\hline-23.64 & -23.63 & 0.01 & 21.74 & 21.95 & 0.95 \\
\hline-23.60 & -23.66 & -0.06 & 21.23 & 19.75 & -7.00 \\
\hline
\end{tabular}




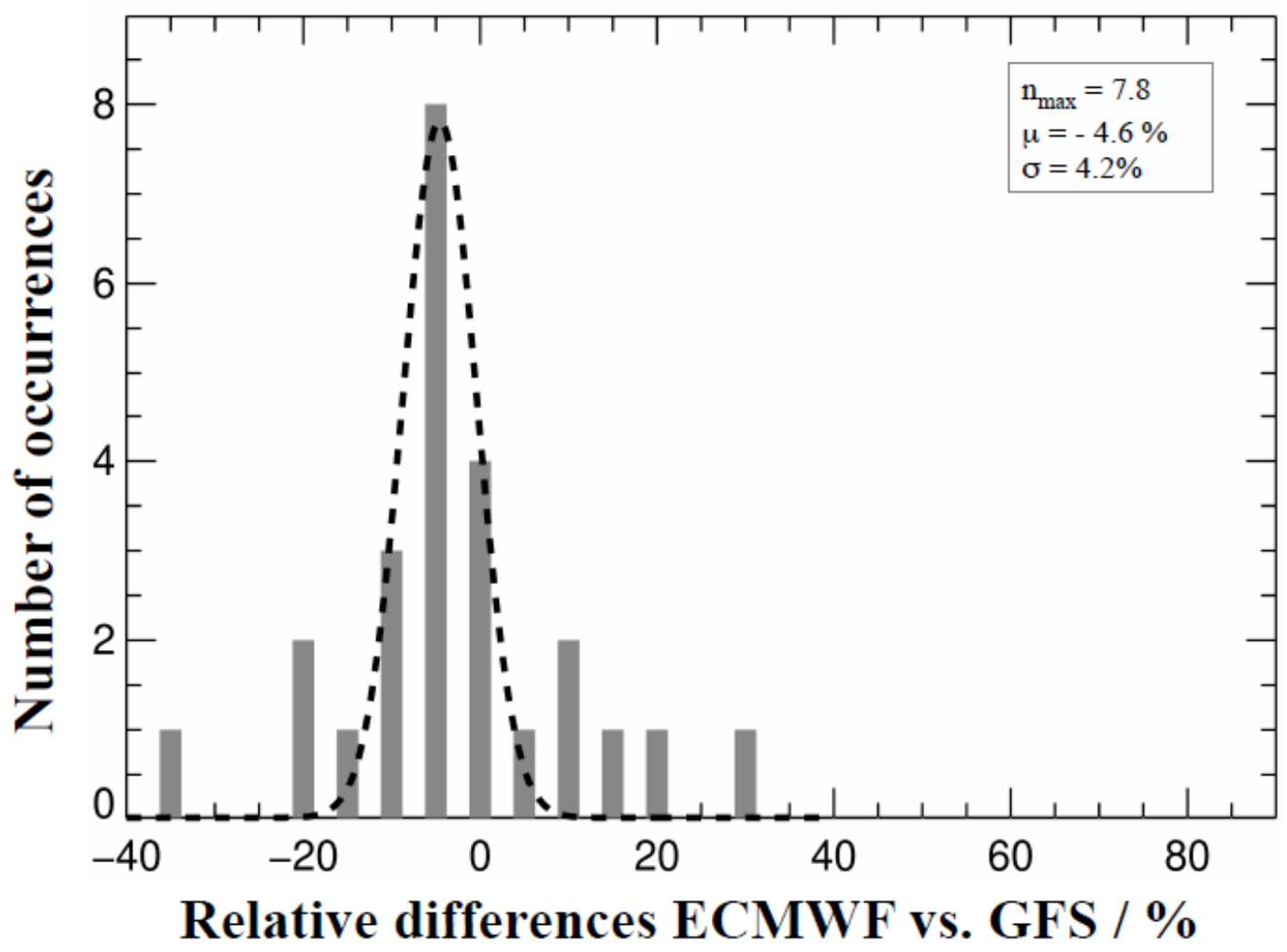

Figure S6.2: Distribution frequency of the relative differences in the calculated concentrations by using ECMWF vs. GFS meteorological data at the STYR site 
Table S7.1: Percentage concentration contribution of each day before sampling to the filter loadings. Discrete categories 'one -', 'two-', 'three days old particles', as well as 'particle older than three days' are given as fractions 210 of the concentration contributions.

\begin{tabular}{|c|c|c|c|c|c|c|c|c|c|c|c|}
\hline Nr. & $\begin{array}{l}\text { Sampling } \\
\text { date } \\
\text { (dd-mm-yy) }\end{array}$ & EIFE & $\begin{array}{c}\text { day } 1 \\
\%\end{array}$ & $\begin{array}{c}\text { day } 2 \\
/ \%\end{array}$ & $\begin{array}{c}\text { day } 3 \\
/ \%\end{array}$ & $\begin{array}{c}\text { day } 4-7 \\
/ \%\end{array}$ & STYR & $\begin{array}{c}\text { day } 1 \\
/ \%\end{array}$ & $\begin{array}{c}\text { day } 2 \\
/ \%\end{array}$ & $\begin{array}{c}\text { day } 3 \\
/ \%\end{array}$ & $\begin{array}{c}\text { day } 4-7 \\
/ \%\end{array}$ \\
\hline 1 & 02-11-15 & & 11.20 & 37.40 & 34.80 & 16.60 & & 38.00 & 33.30 & 19.00 & 9.70 \\
\hline 2 & 06-11-15 & & 35.60 & 36.10 & 19.80 & 8.50 & & 66.70 & 19.30 & 10.20 & 3.84 \\
\hline 3 & 10-11-15 & & 67.50 & 32.50 & 0.00 & 0.00 & & 80.60 & 19.40 & 0.00 & 0.00 \\
\hline 4 & 14-11-15 & & 80.80 & 19.20 & 0.00 & 0.00 & & 92.10 & 7.89 & 0.00 & 0.00 \\
\hline 5 & $22-11-15$ & & 52.60 & 32.10 & 11.40 & 3.99 & & 78.50 & 14.70 & 4.76 & 1.99 \\
\hline 6 & 26-11-15 & & 80.60 & 19.40 & 0.00 & 0.00 & & 95.40 & 4.64 & 0.00 & 0.00 \\
\hline 7 & 08-12-15 & & 19.90 & 42.60 & 16.40 & 21.00 & & 40.10 & 33.50 & 13.70 & 12.70 \\
\hline 8 & $10-02-16$ & & 63.50 & 34.00 & 0.17 & 2.37 & & 72.60 & 23.80 & 0.37 & 3.26 \\
\hline 9 & $14-02-16$ & & 16.20 & 57.00 & 19.80 & 6.96 & & 42.20 & 40.60 & 12.10 & 5.05 \\
\hline 10 & $18-02-16$ & & 6.40 & 18.00 & 30.30 & 45.40 & & 26.70 & 19.60 & 22.30 & 31.40 \\
\hline 11 & $26-02-16$ & & 31.40 & 57.90 & 10.30 & 0.44 & & 81.70 & 17.00 & 1.29 & 0.00 \\
\hline 12 & 05-03-16 & & 22.10 & 76.70 & 1.20 & 0.00 & & 59.70 & 38.60 & 1.74 & 0.00 \\
\hline 13 & 09-03-16 & & 26.60 & 35.90 & 15.10 & 22.40 & & 34.60 & 28.30 & 11.90 & 25.90 \\
\hline 14 & $13-03-16$ & & 29.70 & 36.80 & 10.60 & 22.80 & & 63.20 & 20.30 & 2.14 & 14.40 \\
\hline 15 & $17-03-16$ & & 18.40 & 30.80 & 23.00 & 27.80 & & 55.30 & 24.20 & 8.82 & 11.70 \\
\hline 16 & 19-01-17 & & 45.10 & 33.60 & 7.96 & 13.40 & & 76.90 & 17.90 & 3.27 & 1.95 \\
\hline 17 & $27-01-17$ & & 19.80 & 36.10 & 16.80 & 27.40 & & 32.20 & 31.80 & 16.40 & 19.50 \\
\hline 18 & $12-02-17$ & & 14.20 & 37.50 & 16.80 & 31.50 & & 19.20 & 30.40 & 19.90 & 30.50 \\
\hline 19 & $20-03-17$ & & 63.00 & 37.00 & 0.00 & 0.00 & & 83.80 & 16.20 & 0.00 & 0.00 \\
\hline 20 & 24-03-17 & & 16.30 & 21.10 & 25.60 & 37.00 & & 41.70 & 20.80 & 13.60 & 23.80 \\
\hline 21 & $28-03-17$ & & 41.90 & 23.80 & 22.30 & 11.90 & & 33.60 & 27.30 & 22.90 & 16.20 \\
\hline 22 & 01-04-17 & & 34.50 & 34.50 & 11.10 & 19.90 & & 50.60 & 41.00 & 4.06 & 4.30 \\
\hline 23 & $13-04-17$ & & 69.20 & 30.70 & 0.09 & 0.00 & & 89.10 & 10.90 & 0.02 & 0.00 \\
\hline 24 & $17-04-17$ & & 57.80 & 41.60 & 0.33 & 0.24 & & 82.60 & 16.90 & 0.11 & 0.37 \\
\hline 25 & 21-04-17 & & 27.50 & 47.50 & 16.90 & 8.01 & & 56.70 & 28.80 & 6.78 & 7.69 \\
\hline
\end{tabular}


215 Table S7.2: Basic statistics for $\boldsymbol{t}_{\boldsymbol{a v}, \boldsymbol{t r a j}}$

\begin{tabular}{|c|c|c|c|c|}
\hline Site & Average & $\begin{array}{c}\text { Standard } \\
\text { deviation }\end{array}$ & $\mathrm{N}$ & Error of mean \\
\hline EIFE & $1.6 \mathrm{~d}$ & $0.6 \mathrm{~d}$ & 25 & $0.1 \mathrm{~d}$ \\
\hline STYR & $1.1 \mathrm{~d}$ & $0.5 \mathrm{~d}$ & 25 & $0.2 \mathrm{~d}$ \\
\hline All & $1.3 \mathrm{~d}$ & $0.6 \mathrm{~d}$ & 50 & $0.1 \mathrm{~d}$ \\
\hline
\end{tabular}

Table S7.3: Basic statistics for $\boldsymbol{t}_{\boldsymbol{a v}, \boldsymbol{o b s}}$

\begin{tabular}{|c|c|c|c|c|}
\hline Site & Average & $\begin{array}{c}\text { Standard } \\
\text { deviation }\end{array}$ & N & Error of mean \\
\hline EIFE & $-1.1 \mathrm{~d}$ & $3.8 \mathrm{~d}$ & 25 & $0.8 \mathrm{~d}$ \\
\hline STYR & $-0.3 \mathrm{~d}$ & $3.3 \mathrm{~d}$ & 25 & $0.7 \mathrm{~d}$ \\
\hline All & $-0.7 \mathrm{~d}$ & $3.6 \mathrm{~d}$ & 50 & $0.5 \mathrm{~d}$ \\
\hline
\end{tabular}

Table S7.4: Basic statistics for the difference between $\boldsymbol{t}_{\boldsymbol{a v}, \boldsymbol{t r a j}}$ and $\boldsymbol{t}_{\boldsymbol{a v}, \boldsymbol{o b s}}$

\begin{tabular}{|c|c|c|c|c|}
\hline Site & Average & $\mathrm{N}$ & Error of mean & $\begin{array}{c}\text { Estimated } \delta^{13} \mathrm{C}_{0} \\
/ \% 0\end{array}$ \\
\hline EIFE & $2.7 \mathrm{~d}$ & 25 & $0.8 \mathrm{~d}$ & -24.0 \\
\hline STYR & $1.4 \mathrm{~d}$ & 25 & $0.7 \mathrm{~d}$ & -23.9 \\
\hline All & $2.0 \mathrm{~d}$ & 50 & $0.5 \mathrm{~d}$ & -23.7 \\
\hline
\end{tabular}


225 Table S8.1: Model tracer specifications which are relevant for loss processes. Here the density ( $\rho)$, the diameter (D) of the particles, as well as the $\mathrm{OH}$ reaction constant $\left(\mathrm{k}_{\mathrm{OH}}\right)$ and the coalescence probability $\left(\mathrm{P}_{\text {coal }}\right)$ are given.

\begin{tabular}{|c|c|c|c|c|}
\hline SPECIES & $\begin{array}{c}\boldsymbol{\rho} \\
/ \mathbf{g ~ c m}\end{array}$ & $\begin{array}{c}\mathbf{D} \\
/ \mathbf{\mu m}\end{array}$ & $\begin{array}{c}\mathbf{k}_{\text {oH }} \\
/ \mathbf{~ c m}^{\mathbf{3}} \mathbf{m o l e c}^{-1} \mathbf{s}^{-1}\end{array}$ & $\mathbf{P}_{\text {coal }}$ \\
\hline "inert" & - & - & - & - \\
\hline "chem" & - & - & $2.67 \times 10^{-12}$ & - \\
\hline "drydep" & 1.4 & $0,25 \pm 1,5$ & $2.67 \times 10^{-12}$ & - \\
\hline "wetdep" & 1.4 & $0,25 \pm 1,5$ & $2.67 \times 10^{-12}$ & 1 \\
\hline
\end{tabular}


Table S8.2: Model results obtained for the EIFE station when implementing different loss processes.

\begin{tabular}{|c|c|}
\hline Nr. & $\begin{array}{c}\text { date } \\
\text { (dd-mm-yy) }\end{array}$ \\
\hline 1 & $02-11-15$ \\
\hline 2 & $06-11-15$ \\
\hline 3 & $10-11-15$ \\
\hline 4 & $14-11-15$ \\
\hline 5 & $22-11-15$ \\
\hline 6 & $26-11-15$ \\
\hline 7 & $08-12-15$ \\
\hline 8 & $10-02-16$ \\
\hline 9 & $14-02-16$ \\
\hline 10 & $18-02-16$ \\
\hline 11 & $26-02-16$ \\
\hline 12 & $05-03-16$ \\
\hline 13 & $09-03-16$ \\
\hline 14 & $13-03-16$ \\
\hline 15 & $17-03-16$ \\
\hline 16 & $19-01-17$ \\
\hline 17 & $27-01-17$ \\
\hline 18 & $12-02-17$ \\
\hline 19 & $20-03-17$ \\
\hline 20 & $24-03-17$ \\
\hline 21 & $28-03-17$ \\
\hline 22 & $01-04-17$ \\
\hline 23 & $13-04-17$ \\
\hline 24 & $17-04-17$ \\
\hline 25 & $21-04-17$ \\
\hline
\end{tabular}

\begin{tabular}{|c|c|c|c|c|c|c|c|}
\hline $\begin{array}{l}\mathrm{c} \text { inert } \\
/ \mathrm{ng} \mathrm{m}^{-3}\end{array}$ & $\begin{array}{l}\delta \text { inert } \\
/ \% \text { o }\end{array}$ & $\begin{array}{l}\text { c chem } \\
/ \mathrm{ng} \mathrm{m}^{-3}\end{array}$ & $\begin{array}{c}\delta \text { chem } \\
/ \% \text { o }\end{array}$ & $\begin{array}{c}\text { c } \\
\text { drydep } \\
/ \mathrm{ng} \mathrm{m}^{-3}\end{array}$ & $\begin{array}{c}\delta \\
\text { drydep } \\
/ \% \text { o }\end{array}$ & $\begin{array}{c}c \\
\text { wetdep } \\
/ \mathrm{ng} \mathrm{m}^{-3}\end{array}$ & $\begin{array}{c}\delta \\
\text { wetdep } \\
/ \% \text { o }\end{array}$ \\
\hline 72.77 & -23.37 & 61.12 & -23.01 & 59.79 & -23.02 & 59.79 & -23.02 \\
\hline 26.04 & -23.61 & 24.33 & -23.47 & 23.98 & -23.48 & 23.96 & -23.48 \\
\hline 46.50 & -23.42 & 44.99 & -23.35 & 44.45 & -23.35 & 44.45 & -23.35 \\
\hline 29.89 & -23.54 & 29.18 & -23.49 & 28.93 & -23.49 & 28.93 & -23.49 \\
\hline 20.59 & -23.70 & 19.90 & -23.63 & 19.79 & -23.63 & 19.78 & -23.63 \\
\hline 19.80 & -23.71 & 19.54 & -23.68 & 19.48 & -23.68 & 19.48 & -23.68 \\
\hline 56.48 & -23.41 & 48.25 & -23.10 & 47.07 & -23.11 & 47.03 & -23.11 \\
\hline 27.21 & -23.57 & 26.56 & -23.52 & 26.39 & -23.53 & 26.37 & -23.53 \\
\hline 94.07 & -23.33 & 82.29 & -23.05 & 80.15 & -23.05 & 79.93 & -23.05 \\
\hline 68.62 & -23.40 & 52.52 & -22.86 & 51.00 & -22.88 & 50.91 & -22.88 \\
\hline 39.89 & -23.47 & 37.08 & -23.31 & 36.90 & -23.32 & 36.90 & -23.32 \\
\hline 42.52 & -23.45 & 39.54 & -23.30 & 39.20 & -23.30 & 39.11 & -23.30 \\
\hline 63.00 & -23.39 & 53.01 & -23.05 & 52.15 & -23.06 & 52.10 & -23.06 \\
\hline 42.11 & -23.47 & 36.73 & -23.21 & 36.10 & -23.22 & 36.08 & -23.22 \\
\hline 73.41 & -23.37 & 61.36 & -23.00 & 60.08 & -23.01 & 60.03 & -23.01 \\
\hline 43.86 & -23.45 & 39.74 & -23.26 & 38.99 & -23.27 & 38.93 & -23.27 \\
\hline 81.76 & -23.35 & 67.26 & -22.96 & 65.06 & -22.98 & 65.05 & -22.98 \\
\hline 127.70 & -23.30 & 102.17 & -22.86 & 98.61 & -22.87 & 98.36 & -22.87 \\
\hline 32.47 & -23.52 & 31.61 & -23.46 & 31.37 & -23.46 & 31.37 & -23.46 \\
\hline 76.42 & -23.36 & 62.89 & -22.96 & 61.47 & -22.97 & 61.40 & -22.97 \\
\hline 58.49 & -23.39 & 52.15 & -23.16 & 51.47 & -23.17 & 51.47 & -23.17 \\
\hline 22.59 & -23.68 & 20.86 & -23.52 & 20.72 & -23.53 & 20.72 & -23.53 \\
\hline 19.86 & -23.71 & 19.55 & -23.67 & 19.48 & -23.67 & 19.48 & -23.67 \\
\hline 20.11 & -23.70 & 19.76 & -23.66 & 19.69 & -23.66 & 19.68 & -23.66 \\
\hline 26.88 & -23.60 & 25.12 & -23.46 & 24.98 & -23.46 & 24.98 & -23.46 \\
\hline \multirow{2}{*}{\multicolumn{2}{|c|}{$\begin{array}{r}\text { Mean } \\
\text { of differences }\end{array}$}} & -2.79 & +0.21 & -0.81 & -0.01 & -0.04 & -0.00 \\
\hline & & \multicolumn{2}{|c|}{ chem to inert } & \multicolumn{2}{|c|}{ drydepo to chem } & \multicolumn{2}{|c|}{ wetdep to drydep } \\
\hline
\end{tabular}


Table S8.3: Comparison between the scenarios using a background levoglucosan of $12.4 \mathrm{ng} \mathrm{m}^{-3}$ vs no background

\begin{tabular}{|c|c|c|c|c|c|c|}
\hline & \multicolumn{3}{|c|}{ Background } & \multicolumn{3}{c|}{ No background } \\
\hline Site & Slope & $\begin{array}{c}\text { Std. } \\
\text { Dev. }\end{array}$ & $\mathrm{R}^{2}$ & Slope & $\begin{array}{c}\text { Std. } \\
\text { Dev. }\end{array}$ & $\mathrm{R}^{2}$ \\
\hline EIFE & 1.35 & 0.24 & 0.58 & 1.73 & 0.15 & 0.85 \\
\hline STYR & 1.93 & 0.66 & 0.27 & 2.98 & 0.44 & 0.66 \\
\hline All & 2.08 & 0.43 & 0.33 & 2.61 & 0.28 & 0.64 \\
\hline
\end{tabular}


Table S8.4: Model results obtained with different loss processes for the STYR station.

\begin{tabular}{|c|c|}
\hline $\mathrm{Nr}$. & $\begin{array}{c}\text { date } \\
\text { (dd-mm-yy) }\end{array}$ \\
\hline 1 & $02-11-15$ \\
\hline 2 & $06-11-15$ \\
\hline 3 & $10-11-15$ \\
\hline 4 & $14-11-15$ \\
\hline 5 & $22-11-15$ \\
\hline 6 & $26-11-15$ \\
\hline 7 & $08-12-15$ \\
\hline 8 & $10-02-16$ \\
\hline 9 & $14-02-16$ \\
\hline 10 & $18-02-16$ \\
\hline 11 & $26-02-16$ \\
\hline 12 & $05-03-16$ \\
\hline 13 & $09-03-16$ \\
\hline 14 & $13-03-16$ \\
\hline 15 & $17-03-16$ \\
\hline 16 & $19-01-17$ \\
\hline 17 & $27-01-17$ \\
\hline 18 & $12-02-17$ \\
\hline 19 & $20-03-17$ \\
\hline 20 & $24-03-17$ \\
\hline 21 & $28-03-17$ \\
\hline 22 & $01-04-17$ \\
\hline 23 & $13-04-17$ \\
\hline 24 & $17-04-17$ \\
\hline 25 & $21-04-17$ \\
\hline
\end{tabular}

STYR

\begin{tabular}{|c|c|c|c|c|c|c|c|}
\hline $\begin{array}{l}\mathrm{c} \text { inert } \\
/ \mathrm{ng} \mathrm{m}^{-3}\end{array}$ & $\begin{array}{l}\delta \text { inert } \\
/ \% \text { o }\end{array}$ & $\begin{array}{l}\text { c chem } \\
/ \mathrm{ng} \mathrm{m}^{-3}\end{array}$ & $\begin{array}{c}\delta \text { chem } \\
/ \% \text { o }\end{array}$ & $\begin{array}{c}c \\
\text { drydep } \\
/ \mathrm{ng} \mathrm{m}^{-3}\end{array}$ & $\begin{array}{c}\delta \\
\text { drydep } \\
/ \% \text { o } \\
\end{array}$ & $\begin{array}{c}c \\
\text { wetdep } \\
/ \mathrm{ng} \mathrm{m}^{-3}\end{array}$ & $\begin{array}{c}\delta \\
\text { wetdep } \\
/ \% \text { o } \\
\end{array}$ \\
\hline 93.33 & -23.32 & 82.79 & -23.08 & 81.19 & -23.09 & 81.17 & -23.09 \\
\hline 45.68 & -23.43 & 43.11 & -23.31 & 42.48 & -23.32 & 42.43 & -23.32 \\
\hline 29.28 & -23.54 & 28.84 & -23.51 & 28.66 & -23.51 & 28.66 & -23.51 \\
\hline 26.33 & -23.58 & 26.01 & -23.55 & 25.90 & -23.56 & 25.89 & -23.56 \\
\hline 21.51 & -23.67 & 21.09 & -23.63 & 21.02 & -23.63 & 21.02 & -23.63 \\
\hline 24.42 & -23.61 & 24.29 & -23.59 & 24.26 & -23.60 & 24.26 & -23.60 \\
\hline 65.31 & -23.38 & 57.83 & -23.14 & 56.61 & -23.15 & 56.56 & -23.15 \\
\hline 30.76 & -23.53 & 30.01 & -23.48 & 29.85 & -23.49 & 29.84 & -23.49 \\
\hline 174.18 & -23.27 & 156.79 & -23.05 & 153.04 & -23.06 & 152.61 & -23.06 \\
\hline 96.34 & -23.33 & 77.17 & -22.90 & 75.31 & -22.91 & 75.21 & -22.91 \\
\hline 56.92 & -23.38 & 55.34 & -23.32 & 55.15 & -23.32 & 55.14 & -23.32 \\
\hline 115.15 & -23.29 & 109.19 & -23.18 & 108.63 & -23.18 & 108.46 & -23.18 \\
\hline 78.79 & -23.36 & 65.50 & -23.00 & 64.46 & -23.01 & 64.39 & -23.01 \\
\hline 49.10 & -23.42 & 44.55 & -23.25 & 44.17 & -23.26 & 44.16 & -23.26 \\
\hline 74.97 & -23.35 & 68.17 & -23.16 & 67.43 & -23.17 & 67.41 & -23.17 \\
\hline 53.35 & -23.39 & 51.71 & -23.33 & 51.39 & -23.33 & 51.36 & -23.33 \\
\hline 111.20 & -23.31 & 94.15 & -22.98 & 91.20 & -23.00 & 91.16 & -23.00 \\
\hline 143.88 & -23.29 & 116.08 & -22.86 & 112.43 & -22.88 & 112.18 & -22.88 \\
\hline 34.24 & -23.50 & 33.67 & -23.46 & 33.48 & -23.46 & 33.47 & -23.46 \\
\hline 66.45 & -23.37 & 58.66 & -23.12 & 57.81 & -23.13 & 57.77 & -23.13 \\
\hline 88.98 & -23.33 & 77.59 & -23.05 & 76.52 & -23.06 & 76.51 & -23.06 \\
\hline 39.40 & -23.47 & 37.22 & -23.35 & 36.95 & -23.35 & 36.94 & -23.35 \\
\hline 17.08 & -23.78 & 17.01 & -23.77 & 16.99 & -23.77 & 16.99 & -23.77 \\
\hline 21.96 & -23.65 & 21.77 & -23.64 & 21.75 & -23.64 & 21.74 & -23.64 \\
\hline 22.07 & -23.66 & 21.32 & -23.60 & 21.23 & -23.60 & 21.23 & -23.60 \\
\hline \multirow{2}{*}{\multicolumn{2}{|c|}{$\begin{array}{r}\text { Mean } \\
\text { of differences }\end{array}$}} & -6.43 & +0.16 & -0.88 & -0.01 & -0.05 & -0.00 \\
\hline & & \multicolumn{2}{|c|}{ chem to inert } & \multicolumn{2}{|c|}{ drydepo to chem } & \multicolumn{2}{|c|}{ wetdep to drydep } \\
\hline
\end{tabular}


S9 Details of modeling and measurements results

An overview of the modeling and measurements results are given in the end of this supporting information (Pages 23-28) 245 


\section{References}

Akagi, S. K., Yokelson, R. J., Wiedinmyer, C., Alvarado, M. J., Reid, J. S., Karl, T., Crounse, J. D., and Wennberg, P. O.: Emission factors for open and domestic biomass burning for use in atmospheric models, Atmos. Chem. Phys., 11, 4039-4072, 10.5194/acp-11-4039-2011, 2011.

250 Baumbach, G., Struschka, M., Juschka, W., Carrasco, M., Ang, K. B., Hu, L., Bächlin, D. W., and Sörgel, C.: Modellrechnungen zu den Immissionsbelastungen bei einer verstärkten Verfeuerung von Biomasse in Feuerungsanlagen der 1. BImSchV, Umweltbundesamt, 297, 2010.

Döring, P., Glasenapp, S., and Mantau, U.: Rohstoffmonitoring Holz. Energieholzverwendung in privaten Haushalten 2014. Marktvolumen und verwendete Holzsortimente., Universität Hamburg, 2016.

255 Gensch, I., Sang-Arlt, X. F., Laumer, W., Chan, C. Y., Engling, G., Rudolph, J., and Kiendler-Scharr, A.: Using $\delta 13 C$ of Levoglucosan As a Chemical Clock, Environ. Sci. Technol., 52, 11094-11101, 10.1021/acs.est.8b03054, 2018.

Hueser, I., Harder, H., Heil, A., and Kaiser, J. W.: Assumptions about footprint layer heights influence the quantification of emission sources: a case study for Cyprus, Atmos. Chem. Phys., 17, 10955-10967, 10.5194/acp-17-10955-2017, 2017.

Pfeffer, U., Breuer, L., Gladtke, D., and Schuck, T. J.: Contribution of wood burning to the exceedance of PM10 limit values 260 in north rhine-westphalia, Gefahrstoffe - Reinhalt. Luft, 73, 239-245, 2013.

Seibert, P., and Frank, A.: Source-receptor matrix calculation with a Lagrangian particle dispersion model in backward mode, Atmos. Chem. Phys., 4, 51-63, 10.5194/acp-4-51-2004, 2004. 
Overview EIFE $\quad 1 / 3$

$\delta$ emis $(t=0)=-23.2029 \%$

$\begin{aligned} \delta \text { backgr } & =-23.9931 \% \\ \mathrm{c} \mathrm{backgr} & =12.4 \mathrm{ng} / \mathrm{m}^{3}\end{aligned}$

\begin{tabular}{|c|c|c|c|c|c|c|c|c|c|c|c|c|}
\hline Number & Date & $\begin{array}{l}\delta \text { exp } \\
{[\% 0]}\end{array}$ & $\begin{array}{c}\operatorname{cexp} \\
{\left[n g / m^{3}\right]}\end{array}$ & $\begin{array}{c}\mathrm{mod} \\
[\%]]\end{array}$ & $\begin{array}{c}\mathrm{cmod} \\
{\left[\mathrm{mg} / \mathrm{m}^{3}\right]}\end{array}$ & \begin{tabular}{|c|c|c|} 
backgr mod \\
{$[\%]$}
\end{tabular} & $\begin{array}{c}\substack{\text { emis mod } \\
[\%]} \\
\end{array}$ & Plume (footprint layer, background) & Folded plume (incl. background) & $\begin{array}{c}\text { emis mod day } 1 / 2 / 3 / r \\
{[\%]}\end{array}$ & Emission contribution(d1, d2, d3, r) & Info \\
\hline 1 & 02-11-15 & $-23.70 \pm 0.18$ & $44.66 \pm 4.91$ & -23.02 & 59.79 & 20.74 & 79.26 & & & $11,2 / 37,4 / 34,8 / 16,6$ & & $\begin{array}{l}\text { Sources: South. South-west Germany, Switzerland, Northern Italy, Vosges } \\
\text { (France), (Austria). } \\
\text { - Background: Southern Europe, Mediterranean Sea. } \\
\text { - Model overestimates concentration - unknown loss. Rainv in the south. }\end{array}$ \\
\hline 2 & $06-11-15$ & $-21.30 \pm 0.42$ & $29.39 \pm 3.23$ & -23.48 & 23.96 & 51.75 & 48.25 & & & $35,6 / 36,1 / 19,8 / 08,5$ & -20 & - Background: South-west turope, Meaiterranean Sea, Atlantic Ocean. \\
\hline 3 & 10-11-15 & $-22.89 \pm 0.31$ & $12.36 \pm 1.36$ & -23.35 & 44.45 & 27.90 & 72.10 & & & $67,5 / 32,5 / 00,0 / 0,00$ & -30 & - Model overestimates concentration - unknown loss. \\
\hline 4 & 14-11-15 & $-22.96 \pm 0.37$ & $26.54 \pm 2.92$ & -23.49 & 28.93 & 42.86 & 57.14 & & & $80,8 / 19,2 / 00,0 / 0,00$ & so & $\begin{array}{l}\text { - Background: Atlantic Ocean, northern part. } \\
\text { - Light precipitation. }\end{array}$ \\
\hline 5 & 22-11-15 & $-24.64 \pm 0.80$ & $35.43 \pm 3.90$ & -23.63 & 19.78 & 62.69 & 37.31 & & & $52,6 / 32,1 / 11,4 / 3,99$ & & $\begin{array}{l}\text { - Background: North Sea, Norwegian Sea. } \\
\text { - Precipitation. }\end{array}$ \\
\hline 6 & $26-11-15$ & $-23.13 \pm 0.23$ & $38.51 \pm 4.24$ & -23.68 & 19.48 & 63.65 & 36.35 & & & $80,6 / 19,4 / 00,0 / 0,00$ & & $\begin{array}{l}\text { - Background: Norwegian Sea, incl. Iceland and Greenland. } \\
\text { Light precipitation. }\end{array}$ \\
\hline 7 & 08-12-15 & $-23.17 \pm 0.15$ & $70.23 \pm 7.73$ & -23.11 & 47.03 & 26.37 & 73.63 & & & $19,9 / 42,6 / 16,4 / 21,0$ & & $\begin{array}{l}\text { - Background: Mediterranean Sea, Atlantic Ocean. } \\
\text { - Precipitation. }\end{array}$ \\
\hline & & & & & & & & $3^{3}$ & & & 3 & $\begin{array}{l}\text {-Sources: West, (North-West). Luxemburg, Northern France, GB, } \\
\text { (scandinavia). } \\
\text { - Background: Norwegian Sea, Alantic Ocean (Iceland, Greenland). }\end{array}$ \\
\hline 8 & $10-02-16$ & $-24.37 \pm 0.42$ & $18.18 \pm 2.00$ & -23.53 & 26.37 & 47.02 & 52.98 & & & $63,5 / 34,0 / 0,17 / 2,37$ & 30 & - Precipitation. \\
\hline
\end{tabular}




\section{Overview EIFE $2 / 3$}

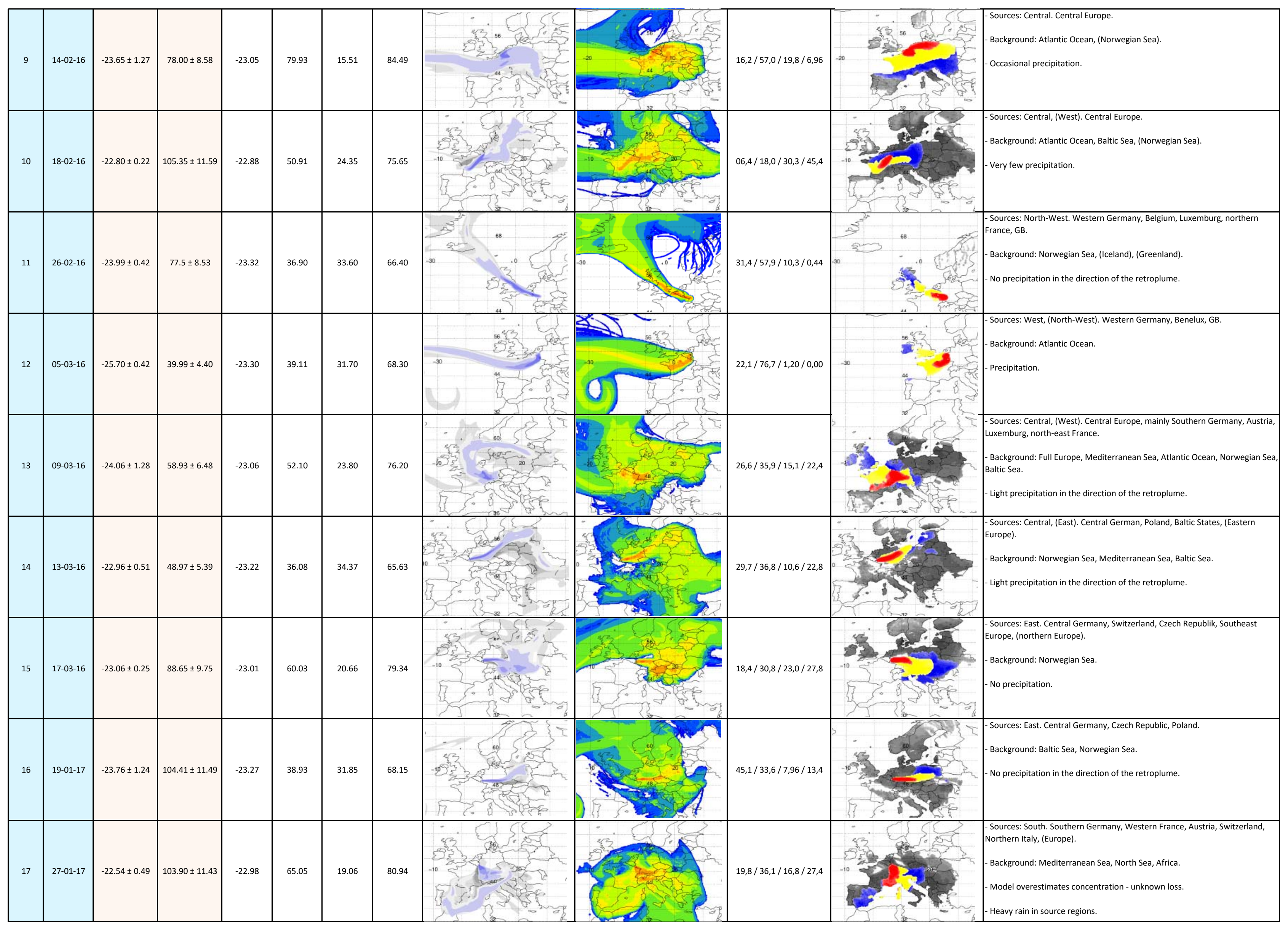




\section{Overview EIFE $3 / 3$}

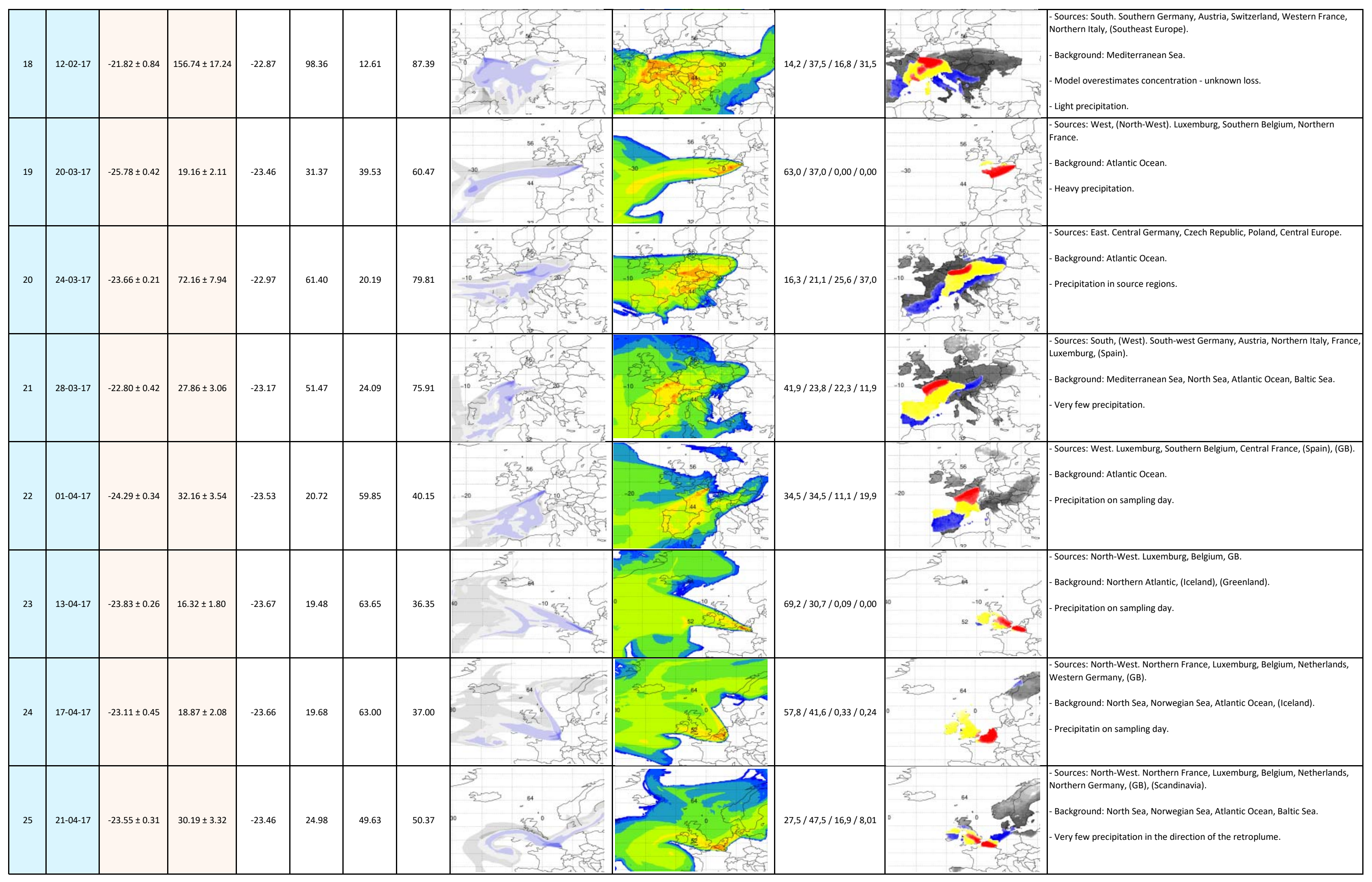


Overview STYR $1 / 3$

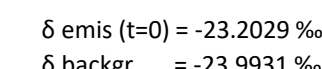

$\begin{aligned} & \delta \text { backgr }=-23.9931 \% \\ & \text { c backgr }=12.4 \mathrm{ng} / \mathrm{m}^{3}\end{aligned}$

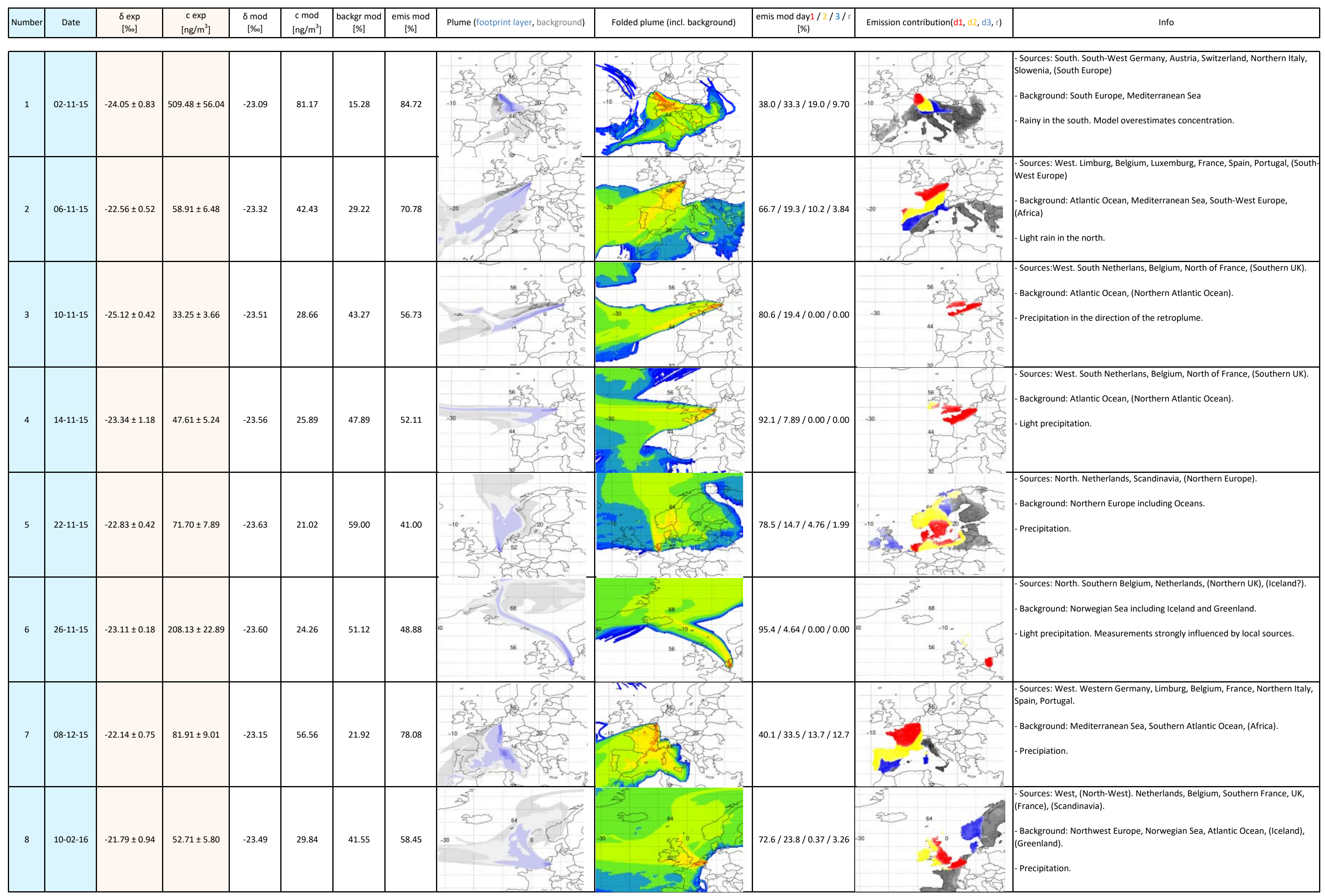




\section{Overview STYR 2/3}

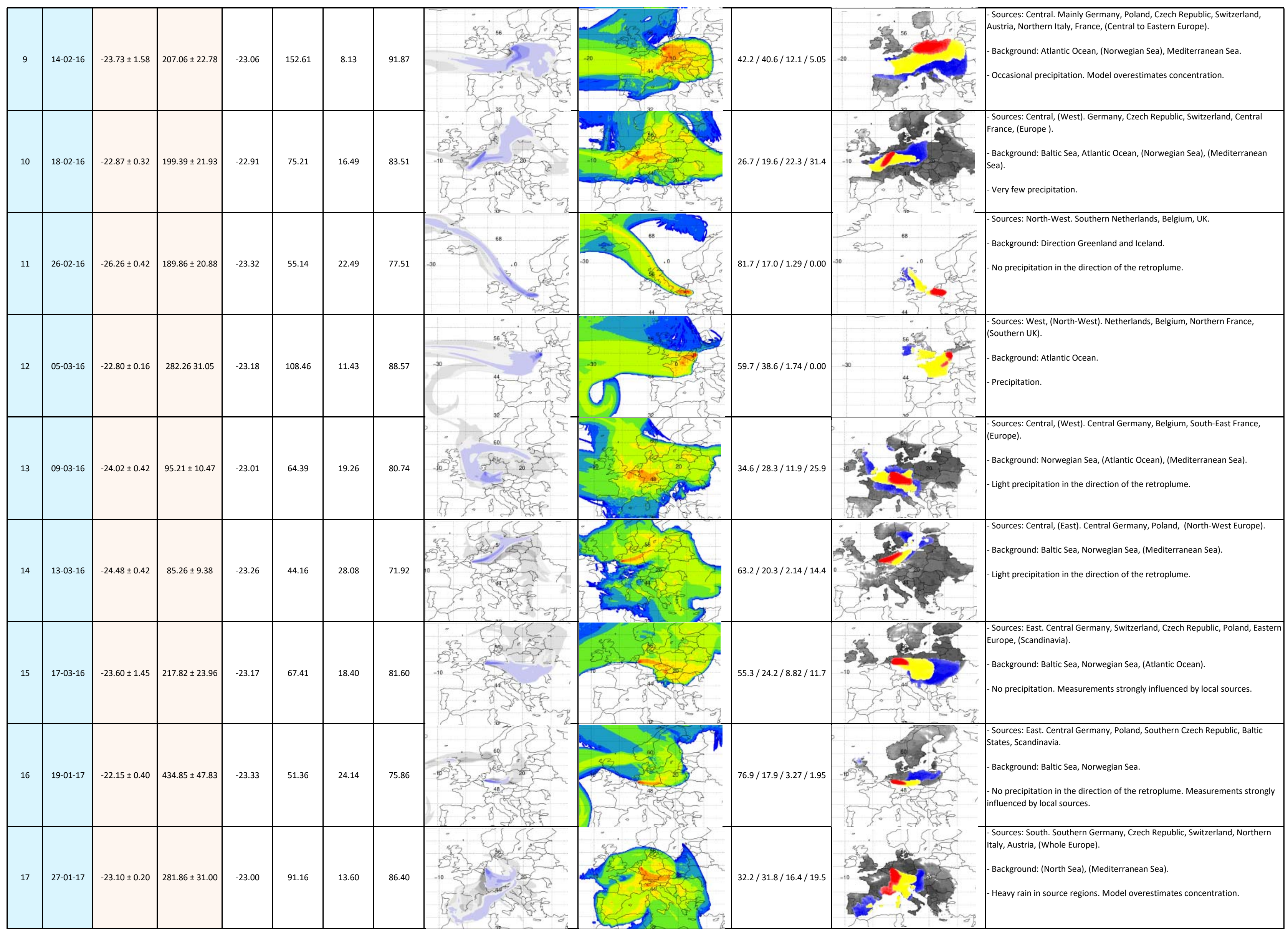




\section{Overview STYR $3 / 3$}

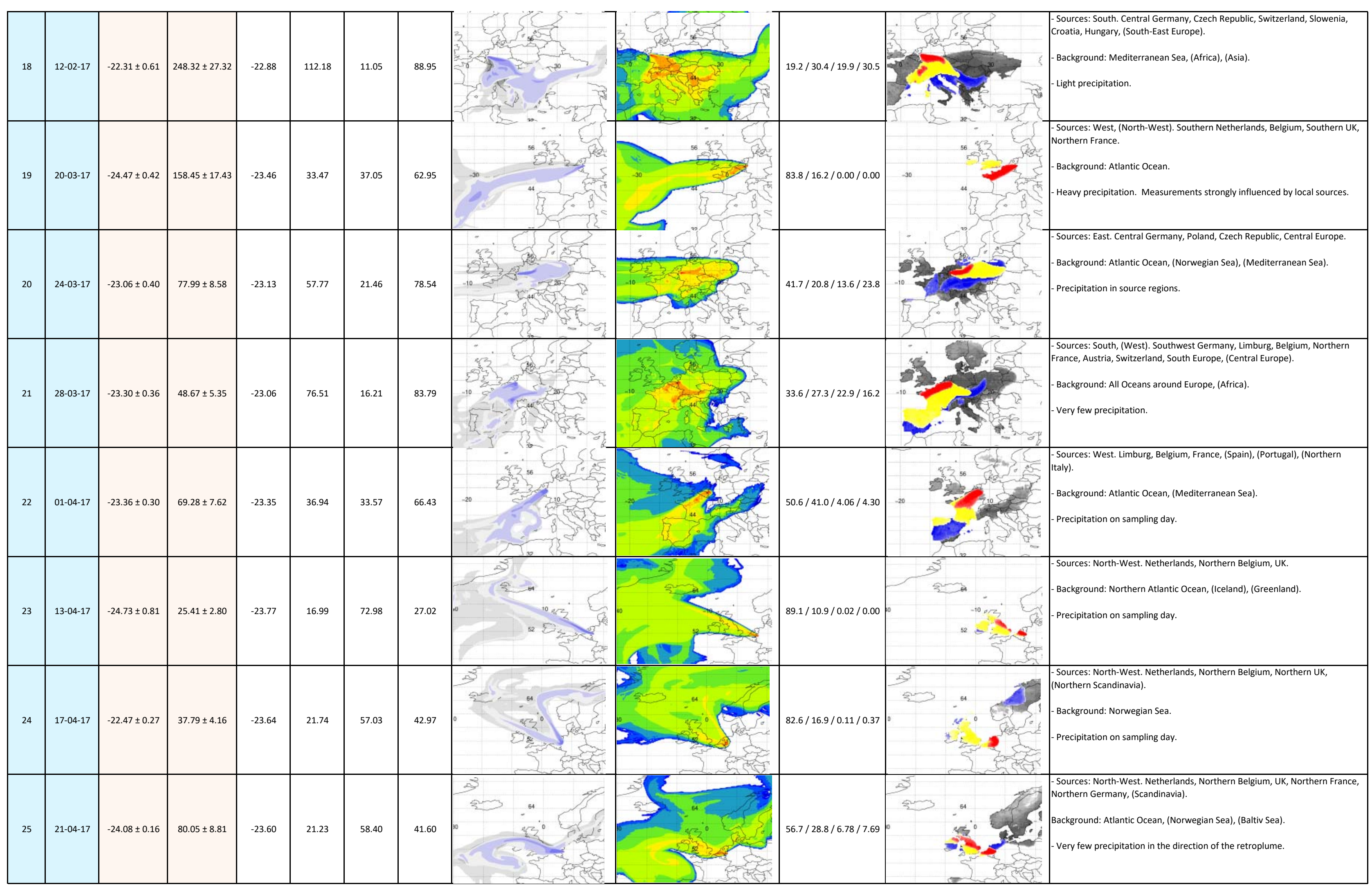

